\title{
EU INTERNATIONAL FAMILY LAW AND THIRD STATES
}

\author{
Katarína Burdová ${ }^{1}$ \\ Comenius University in Bratislava, Faculty of Law
}

\begin{abstract}
The aim of this contribution is to consider whether common provisions of the Brussels IIbis Regulation and of the Maintenance Regulation supersede the national rules only in so far as a given situation has substantial connections to the EU or in all situations irrespective of such connections. We will consider external effect (effect on extra-Union cross-border family cases) of the abovementioned Regulations on the basis of analysis of personal-territorial scope of their application.
\end{abstract}

Key words: EU international family law, personal-territorial scope, Brussels IIbis Regulation, Maintenance Regulation

\section{INTRODUCTION}

The European Union" (hereinafter referred to as "the EU“), through the exercise of internal and external competences ${ }^{3}$, adopted several measures in the area of cross-border family law ${ }^{4}$.

The aim of the EU acting at the EU level in the area of international family law is the unification of private international rules between the EU Member States ${ }^{5}$ for the purpose of increasing decisional harmony in the EU. In this area, the EU adopted several regulations. The most important are the Brussels IIbis Regulation ${ }^{6}$ and the Maintenance Regulation ${ }^{7}$. These Regulations have direct effect in the EU Member States; nevertheless, they are surely not mandatory nor applicable in third States.

1 This article has been financed by VEGA Agency of Ministry of Education, Science, Research and Sport of the Slovak Republic as a project No. 1/0485/14 - „The dynamics of family relations legal regulation in European area as a challenge for Slovak private international law."

2 The EU has no competence in the sphere of pure domestic family law; however, the Union is tasked by the Treaties to develop judicial cooperation in family matters having cross-border implications.

3 Aude Fiorini states: “There are three main forms that the exercise of this (EU) competence can take.

First, the EU may (in accordance with the provisions of the Treaties) take EU-wide measures (Art. 81 TFEU). Second, the EU may authorise Member States, inter se, to establish family law measures (article 20). Third, it is also conceivable that this competence might be exercised through the participation of the EU in international family law instruments having a broader scope of application than the EU region (Art. 216 TFEU). In: Directorate-general for internal policies. Which Legal basis for Family law? The way forward.

Available at: http://www.europarl.europa.eu/RegData/etudes/note/join/2012/462498/IPOL-JURI_NT(2012)462498_EN.pdf

4 E.g. The Council Regulation (EU) No 1259/2010 of 20 December 2010 harmonised the law applicable to divorce and legal separation, but was adopted on the basis of enhanced cooperation; the EU has ratified the Hague Conference's Protocol of 23 November 2007 on the Law Applicable to Maintenance Obligations; the EU authorised the Member States to ratify, or accede to, the 1996 Hague Child Protection Convention etc.

5 Denmark, Ireland and the UK do not participate in any EU family law measures. However, the UK and Ireland may decide to take part.

6 The Council Regulation (EC) No 2201/2003 of 27 November 2003 concerning jurisdiction and the recognition and enforcement of judgments in matrimonial matters and the matters of parental responsibility, repealing Regulation (EC) No $1347 / 2000$

7 The Council Regulation (EC) No 4/2009 of 18 December 2008 on jurisdiction, applicable law, recognition and enforcement of decisions and cooperation in matters relating to maintenance obligations 
The Brussels IIbis Regulation involves rules of jurisdiction, rules of lis pendens and rules of recognition and enforcement of judgement in matrimonial matters (i.e. divorce, legal separation or marriage annulment) and matters of parental responsibility. The Maintenance Regulation covers rules of jurisdiction, rules of lis pendens and rules of recognition and enforcement of judgement in matters relating to maintenance obligations as well as applicable law by means of referring to the conflict of law rules as stipulated by the Hague Protocol ${ }^{8}$.

The aim of this contribution is to consider whether common provisions of the Brussels IIbis Regulation and of the Maintenance Regulation supersede the national rules only in so far as a given situation has substantial connections to the EU or in all situations irrespective of such connections. We will consider external effect (effect on extra-Union cross-border family cases) of the abovementioned Regulations on the basis of analysis of their personal-territorial scope of application.

\section{BRUSSELS IIBIS REGULATION AND THIRD STATES}

The Brussels IIbis Regulation contains private international rules on matrimonial matters and on parental responsibility matters. While considering whether the application of unified rules under this Regulation is limited only to intra-Union situations, it is necessary to analyse separately rules concerning jurisdiction, rules concerning lis pendens as well as rules concerning recognition and enforcement of judgements.

Rules regarding lis pendens and dependent actions are contained in Article 19 of the Brussels IIbis Regulation. These provisions are applicable in cases where proceedings relating to divorce, legal separation or marriage annulment or proceedings relating to parental responsibility are brought before courts of different Member States of the EU. It is clear that the purpose of these rules is to distribute the competence to hear a dispute among courts of the EU Member States. In consequence, it may be concluded that the rules contained in Article 19 of the Brussels IIbis Regulation are applicable only to intra-Union situations. An intra-Union situation means that parallel proceedings are brought before courts of different Members States. Still, it does not mean that in a particular case, the dispute has no connection to a third State. Article 19 is applicable also in situations where courts of the Member States base their jurisdiction on national rules (on the basis of Article 7 or Article 14 of the Brussels IIbis Regulation) where e.g. a child has his/her habitual residence outside the EU but e.g. a parent is an EU Member State citizen or a plaintiff, a defendant or either of them has his/ her habitual residence in an EU Member State etc. ${ }^{\text {. }}$

Article 19 of the Brussels IIbis Regulation is not applicable to coordination of the exercise of jurisdiction by courts of the Member States and courts of third States. The question whether a court of a Member State can decline jurisdiction under the Brussels IIbis Regulation on the basis of national lis pedens rules (or on the basis of forum non conveniens rules, or on the basis of cases where discretion to stay proceedings needs to be applied) in favour of a court of a third State has not been considered by the European Court of Justice ("the ECJ") till now. This question was answered by

8 The Hague Protocol of 23 November 2007 on the Law Applicable to Maintenance Obligations.

9 For more information on residual jurisdiction rules of the Member States under the Brussels II bis Regulation, consult NUYTS, A.: Study on residual jurisdiction. Review of the Member State's Rules concerning the „Residual Jurisdiction“ of their courts in Civil and Commercial Matters pursuant to the Brussels I and II Regulations.

Available at: http://www.ec.europa.eu/civiljustice/news/docs/study_residual_jurisdiction_en.pdf 
the ECJ in the case Owusu which deals with the Brussels I Regulation ${ }^{10}$. In the case Owusu, the ECJ decided that national courts could not decline jurisdiction under Article 2 of Brussels I Regulation in favour of courts of non-Member States even if the jurisdiction of no other Member State is in issue or if the proceedings have no connecting factors to any other Member State.

Are the case Owusu conclusions applicable to the Brussels IIbis Regulation as well? In other words, if the common European rules of lis pendens under the Brussels IIbis Regulation are not applicable to the coordination of parallel proceedings in a Member State and in a third State, can national rules on lis pendens according to the lex fori of a Member State be applicable to such a situation? The answer to this question is not clear but, according to some interpretations, national rules are applicable to parallel proceedings in third States, but only if and to the extent that they do not impair nor impede the full effectiveness of the European regime on jurisdiction ${ }^{11}$. There is also a very interesting opinion that in parental responsibility disputes, "the combined effect of the habitual residence and lis pendens rules can cause significant injustice to litigants and harm the interests of their children. Given the fundamental nature of the child's best interest principle (no doubt a jus cogens norm), the courts can justify the deferral of proceedings to a more suitable jurisdiction in violation of the possible prohibition in the Brussels IIbis in respect of deferrals and stays" ${ }^{2}$.

According to the Chapter III of Brussels IIbis Regulation, common European rules on recognition or enforcement of foreign judgments are applicable only in an intra-Union situation where a judgment given in one EU Member State shall be recognized in the other EU Member States. Common European rules are not applicable on third State's judgements recognition which is regulated by national law of the EU Member States. Despite the fact that the EU common rules are applicable only in a situation with significant connection to the EU, it does not mean that a judgment given in one Member State has no connection to third States. For instance, recognition of a divorce judgement given in a EU Member State concerning divorce of two nationals of a third State with the last common habitual residence outside the $\mathrm{EU}$ is governed by common EU rules on recognition in another EU Member States.

The Brussels IIbis Regulation contains two sets of rules of jurisdiction. First, the rules regulating jurisdiction in matrimonial matters (Articles 3 to 7 of Brussels IIbis Regulation) and, second, the rules of jurisdiction in the matters of parental responsibility (Articles 8 to 10 and Articles 12 to 15 of Brussels IIbis Regulation).

While considering the jurisdiction in matrimonial matters under the Brussels IIbis Regulation, it may seem that personal-territorial scope of these provisions is expressed in Article 6 of Brussels IIbis Regulation which states that there is no room for application of rules of national jurisdiction (residual jurisdiction) under Article 7 of the Brussels IIbis Regulation ${ }^{13}$ if a respondent has his/her

10 The Council Regulation (EC) No 44/2001 of 22 December 2000 on jurisdiction and the recognition and enforcement of judgments in civil and commercial matters.

11 MANGUS, U. - MANKOWSKI, P. (eds.): Brussels IIbis Regulation. European Commentaries on Private International law. Munich: Sellier European law publishers, 2012, p. 226.

12 BANTEKAS, I.: The pitfalls of lis pendens in transnational matrimonial jurisdiction disputes before English courts, p. 13. Available at:

http://www.google.sk/url?sa=t\&rct=j\&q=\&esrc=s\&source=web\&cd=9\&ved=0ahUKEwiYjJmUrJvQAhUmD8AKH WpiDkkQFghLMAg\&url=http\%3A\%2F\%2Fbura.brunel.ac.uk\%2Fbitstream\%2F2438\%2F12704\%2F1\%2FFulltext. doc\&usg=AFQjCNFPRd2VY-PinAwRBA9jN2pRtYNODQ

13 Residual jurisdiction according to the Article 7 of the Brussels IIbis Regulation is a jurisdiction which shall be determined by national law (not by common European rules) of a Member State. 
habitual residence in the territory of a EU Member State or is a national of a EU Member State or, in the case of the United Kingdom and Ireland, has his/her "domicile" in the territory of these States. According to some commentators, Article 6 refers to the distinction between Union disputes and extra-Union disputes ${ }^{14}$. It may appear that in Union disputes, common rules of jurisdiction according to Articles 3 to 5 are applicable and in extra-Union cases, where a respondent has his/her habitual residence in a third State or is a national of a third State, rules of national jurisdiction are applicable.

Nevertheless, according to the ECJ, such opinion is an erroneous interpretation. In the case Sundelind Lopez, the ECJ clarified that "Articles 6 and 7 of the Brussels IIbis Regulation are to be interpreted as meaning that where, in divorce proceedings, a respondent is not habitually resident in a Member State and is not a national of a Member State, the courts of a Member State cannot base their jurisdiction to hear the petition on their national law, if the courts of another Member State have jurisdiction under Article 3 of that Regulation“. It means, inter alia, that Article 6 of Brussels IIbis Regulation is not a general scope rule. The fact that the Brussels IIbis Regulation does not contain a specific provision on the personal-territorial scope of its rules of jurisdiction in matrimonial matters means that common rules of jurisdiction (Articles 3 to 5) have to be considered in all cases despite the existence of substantial connection to third States. For example, in a situation where a marriage of two nationals of a non-Member State was concluded in a third State and they have common habitual residence in third States only, a Slovak court, in considering its jurisdiction, shall apply common European rules of jurisdiction and not national rules, if an applicant is a habitual resident in an EU Member State and if he/she resided there for at least a year immediately before the application was made.

To conclude this part, it can be stated that the application of common European rules of jurisdiction in matrimonial matters is not limited to intra-Union disputes but common rules are applicable also where a dispute has significant connection to a third State.

With regard to the rules on jurisdiction in matters on parental responsibility, the Brussels IIbis Regulation does not contain a provision on its personal-territorial scope and the Article 14 refers to "residual jurisdiction" that may be conferred by the national law within the forum of a EU Member State.

When we take into consideration the fact that "the fundamental principle of the jurisdiction rules in matters of parental responsibility is that the most appropriate forum is the relevant court of the Member State of the habitual residence of the child"15 and given that the Articles 9, 10, 12 and 13 set out exceptions to the general rule, indicating where jurisdiction may lie with the courts of a Member State other than that in which the child is habitually resident ${ }^{16}$, it may be concluded that common jurisdictional rules are applicable only in a situation where the child is a habitual resident within the EU, where the child's habitual residence cannot be established or where the child is present within the EU and, in all other cases, rules of national jurisdiction of the lex fori of a EU Member State are applicable according to Article 14 of Brussels IIbis Regulation.

Having analysed the jurisdictional rules of the Brussels IIbis Regulation in more detail, we arrive at another conclusion. As Professor De Boer points out, Article 8 of Brussels IIbis Regulation is

14 MANGUS, U. - MANKOWSKI, P. (eds.): Brussels IIbis Regulation. European Commentaries on Private International law, p. 104.

15 European Commission: Practical Guide for the application of the Brussels IIa Regulation. Avaliable at: http://www.ec.europa.eu/justice/civil/files/brussels_ii_practice_guide_en.pdf p. 25.

16 European Commission: Practical Guide for the application of the Brussels IIa Regulation. Avaliable at: http://www.ec.europa.eu/justice/civil/files/brussels_ii_practice_guide_en.pdf p. 30. 
applicable not only in a situation where the child is a habitual resident in a EU Member States, but also in a situation where the child subsequently moves to a third State. It is the consequence of the perpetuatio fori principle involved in Article 8 of Brussels IIbis Regulation ${ }^{17}$. Professor De Boer ${ }^{18}$ also points to Article 12 of Brussels IIbis Regulation. For the needs of the application of Article 12(1), as well as Article 12(3) of Brussels II bis Regulation, neither habitual residence of a child nor his/her nationality are relevant. In particular, Article 12(3) of Brussels IIbis Regulation is potentially applicable in disputes with significant connection to a third State.

To conclude this part, it can be stated that the application of common European rules of jurisdiction in matters of parental responsibility is generally not limited to situations where the child has his/ her habitual residence within the EU.

\section{MAINTENANCE REGULATION AND THIRD STATES}

Rules of jurisdiction laid by the Maintenance Regulation are unlimited in their territorial scope; therefore, the application of these provisions is direct and universal and is extended to persons living in third States. These common European jurisdictional rules leave no room for the application of rules of national jurisdiction.

Conversely, lis pendens rules as well as rules on recognition and enforcement of judgements are limited to an intra-Union situation, similarly to the Brussels IIbis Regulation provisions of lis pendens and recognition and enforcement. The fact that jurisdiction rules are universal but lis pendens rules are limited to intra-Union situations may give rise to the question whether national rules of lis pendens are applicable in a situation where a dispute has significant connection to third States. In other words, are the conclusion of the case Owusu applicable within the Maintenance Regulation regime? The answer to this question remains unclear and the ECJ will have to provide us with their position on the issue.

\section{CONCLUSION}

Universal personal-territorial scope of application of jurisdictional rules of the Brussels IIbis Regulation may be of confusing nature because it does not require an identification of intra-Union aspect of dispute as in the case of the Brussels I Regulation but "a three-step reasoning: does the court in the EU that is seized have jurisdiction according to the Brussels IIbis Regulation's rules; if not, does another court in the EU have jurisdiction according to the Brussels IIbis Regulation's rules; if not, a court may look at its domestic bases of jurisdiction"19. In contrast, the Maintenance Regulation, which also has a universal scope of jurisdictional rules, does not require such an assessment. These differences can cause problems for courts of the EU Member States, which often apply both Regulations in one procedure and confuse unskilled parties.

17 DE BOER, Th. M.: What we should not expect from a recast of the Brussels IIbis Regulation. In: NIPR, 2015, 1, p. 16.

18 Ibid., p. 13.

19 Kruger, T.: The Disorderly infiltration of EU law in Civil procedure. In: NILR, 2016, p. 7. 
The extension of scope of application of jurisdictional rules in matters of parental responsibility under the Brussels IIbis Regulation to situations where the child has not habitual residence within the EU territory is criticised by Professor de Boer for, among other things, the likelihood that the court's decision will not be recognized outside the EU, the problems regarding taking the evidence in the third States and the conflict between the Brussels IIbis Regulation and other sources like the 1996 Hague Convention.

In contrast, the limited scope of the common rules of recognition and enforcement of judgements of both Regulations and application of national rules for assessment of res iudicata effects of third States judgments in a Member State may lead to forum shopping. Adoption of a common provision on basic principles under which a third State judgement may be recognized and enforced in all Member States would be welcome but appears to be unlikely at present.

The existing multilateral treaty solution with third States achieved at the Hague Conference on Private International law currently remains a preferable and an appropriate solution.

\section{Bibliography:}

BANTEKAS, I.: The pitfalls of lis pendens in transnational matrimonial jurisdiction disputes before English courts. Available at: http://www.google.sk/url?sa=t\&rct=j\&q=\&esrc=s\&source=web\&cd=9\&ved=0ahUKEwiYjJmUrJvQ AhUmD8AKHWpiDkkQFghLMAg\&url=http\%3A\%2F\%2Fbura.brunel.ac.uk\%2Fbitstream\%2F2438\%2F12704 \%2F1\%2FFulltext.doc\&usg=AFQjCNFPRd2VY-PinAwRBA9jN2pRtYNODQ

DE BOER, Th. M.: What we should not expect from a recast of the Brussels IIbis Regulation. In: NIPR, 2015, 1, p. 1-23.

EUROPEAN COMMISSION: Practical Guide for the application of the Brussels IIa Regulation. Avaliable at: http:// www.ec.europa.eu/justice/civil/files/brussels_ii_practice_guide_en.pdf

DIRECTORATE-GENERAL FOR INTERNAL POLICIES. Which Legal basis for Family law? The way forward.

Available at: http://www.europarl.europa.eu/RegData/etudes/note/join/2012/462498/IPOL-JURI_NT(2012)462498_ EN.pdf

MANGUS, U. - MANKOWSKI, P. (eds.): Brussels IIbis Regulation. European Commentaries on Private International law. Munich: Sellier European law publishers, 2012.

NUYTS, A.: Study on residual jurisdiction. Review of the Member State's Rules concerning the „Residual Jurisdiction“ of their courts in Civil and Commercial Matters pursuant to the Brussels I and II Regulations.

\section{Contact information:}

JUDr. Katarína Burdová, PhD.

katarina.burdova@flaw.uniba.sk

Comenius University in Bratislava

Šafárikovo námestie 1,

Bratislava

81000

Slovakia 